\title{
Conformational equilibria involving 2-amino-1,3-dioxans: steric control of the anomeric effect
}

\author{
Anthony J. Kirby* and Peter D. Wothers \\ University Chemical Laboratory, Cambridge CB2 1EW, UK \\ E-mail:ajkl@cam.ac.uk \\ Dedicated to Ossie Tee, with respect and affection \\ (received 09 Sep 01; accepted 28 Oct 01; published on the web 05 Nov 01)
}

\begin{abstract}
Although $N, N, 1$-trimethylcyclohexamine exists in two equilibrating conformations, with the $\mathrm{NMe}_{2}$ group axial and equatorial in comparable amounts, in N,N,2-trimethyl-2-amino-1,3dioxane the conformation with the amine equatorial could not be detected; evidence for an anomeric effect for the $\mathrm{NMe}_{2}$ group of $>3 \mathrm{~kJ} \mathrm{~mol}^{-1}$. When the $\mathrm{NMe}_{2}$ group is axial in the dioxane, there can be no exo-anomeric effect (this would mean placing a methyl group over the ring), but the endo-anomeric effect is unaffected. Calculations show that when the $\mathrm{NMe}_{2}$ group is equatorial, the rotamer lowest in energy is one in which an exo-anomeric effect is possible, despite the steric demands involved. Thus the endo-anomeric effect in N,N,2-trimethyl-2-amino1,3-dioxane is greater than the exo-anomeric effect, even though amine nitrogen is generally a better electron-pair donor than oxygen.
\end{abstract}

Keywords: Anomeric effect, steric control, 2-amino-1,3-dioxans, conformational equilibria

\section{Introduction}

The generalized anomeric effect ${ }^{1}$ refers to the predilection for gauche conformations of systems such as 1, with two heteroatoms on the same carbon. Any conformational effect is the result of a combination of steric, electronic and electrostatic influences, but there is substantial theoretical support $^{2}$ for charge demoralization derived from hyperconjugation (arrows in 1) as the primary cause of the anomeric effect. The effect is stronger for more electronegative groups $\mathrm{X}$, and for better electron-pair donors (which may be lone pairs, as in $\mathbf{1}$, or even $\sigma$-bonding electrons ${ }^{1}$ ), as the $\mathrm{n}_{\mathrm{O}-\sigma^{*} \mathrm{C}-\mathrm{X}}$ interaction (arrows in 1) becomes more important. We report results with an $\mathrm{O}-$ $\mathrm{C}-\mathrm{N}$ system, which shows an unexpectedly large anomeric effect. 


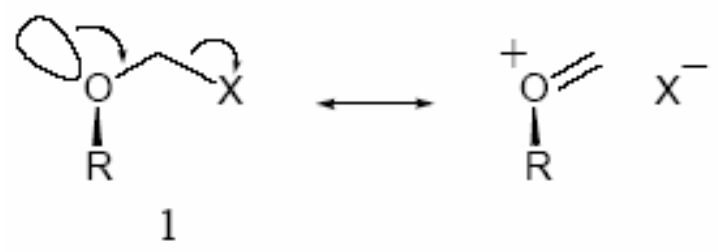

As part of our investigation of the putative reverse anomeric effect ${ }^{3,4}$ we were interested in systems $\mathbf{3}$ and $\mathbf{4}$. $\mathbf{3}$ is readily made by alkylation of amide acetal $\mathbf{2}$ with methyl iodide at room temperature. ${ }^{5}$

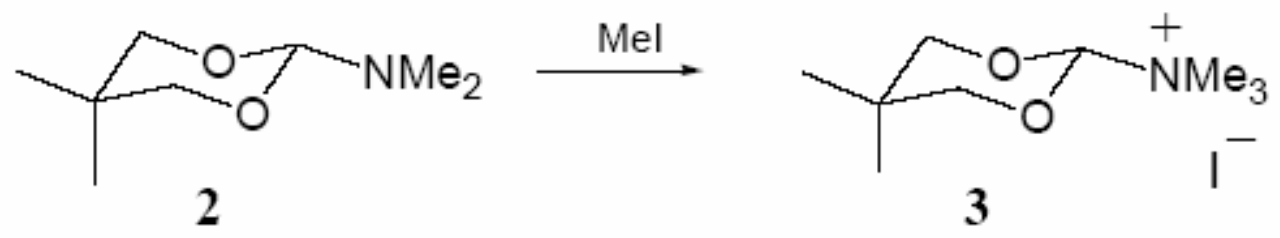

The equatorial protons on $\mathrm{C} 4$ and $\mathrm{C} 6$ of 2 resonate downfield of their geminal proton partners (as is normal for THPs and cyclohexanes), but in the quaternary ammonium compound 3 the order is reversed: the axial protons $\mathrm{H}(4)$ and $\mathrm{H}(6)$ appearing downfield of their equatorial counterparts. The same effect $\left[\delta_{\mathrm{H}}\left(4_{\mathrm{ax}}\right)>\delta \mathrm{H}\left(4_{\mathrm{eq}}\right)\right]$ has been noted before in 2-alkoxy-1,3dioxanes, where it was ascribed to the axial preference of the alkoxy group, ${ }^{6,7}$ but nOe experiments confirmed that in 3 the ${ }^{+} \mathrm{NMe}_{3}$ group is indeed equatorial. Intending to characterize the conformation with the ${ }^{+} \mathrm{NMe}_{3}$ group axial we set out to make compound 4 , with a sterically balancing methyl group on $\mathrm{C} 2$.

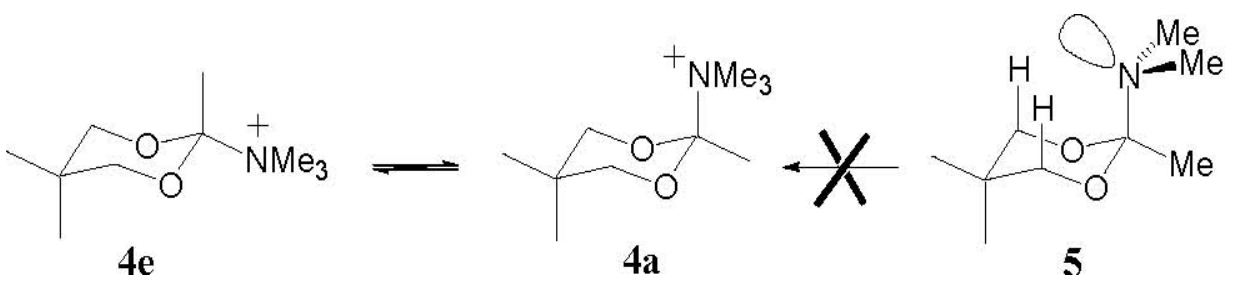

Amide acetal 5 was readily made by reacting $N, N$-dimethylacetamide dimethylacetal with the appropriate diol, but proved impossible to methylate using methyl iodide, or even trimethyloxonium tetrafluoroborate. nOe experiments revealed that $\mathbf{5}$ actually exists in the conformation with the $\mathrm{NMe}_{2}$ group axial. (The ${ }^{1} \mathrm{H} \mathrm{NMR}$ shifts of the axial and equatorial protons in $\mathbf{5}$ are 3.82 and 3.10 respectively, confirming the preferred conformation.) We presume that $\mathbf{5}$ is difficult to methylate because the axial $\mathrm{NMe}_{2}$ group has its lone pair situated directly over the dioxane ring, thus sterically inhibiting its nucleophilicity. Allinger and Graham have shown that the dimethylamino group in a cyclohexane ring is alkylated 50 times more slowly when axial than when equatorial. ${ }^{8}$ In a dioxane the transition state would be yet more crowded, because $\mathrm{C}$ $\mathrm{O}$ bonds are shorter than $\mathrm{C}-\mathrm{C}$.

Because amine nitrogen is less electronegative than oxygen, groups such as $\mathrm{NH}_{2}$ show the 
usual steric preference for an equatorial configuration and only a small anomeric effect. A-values for the $\mathrm{NH}_{2}, \mathrm{NHMe}$ and $\mathrm{NMe}_{2}$ groups are 1.23, 1.29 and 1.53, respectively, ${ }^{9}$ all smaller than the value of 1.74 for $\mathrm{CH}_{3}$, so that 5 is expected to prefer the conformation with the dimethylaminogroup axial by a small margin. The fact that no trace could be detected of the conformer of amide acetal 5 with the dimethylamino-group equatorial was thus unexpected, and provided an opportunity to estimate the size of the anomeric effect associated with the dimethylamino group.

Care must be taken when using A-values alone when trying to distinguish between steric and electronic effects. For example, 2-methylaminotetrahydropyran (see discussion, below) shows a stronger preference than methylaminocyclohexane for the equatorial conformation, leading Booth and Khedhair ${ }^{10}$ to conclude that the NHMe group has a small reverse anomeric effect. However, this conclusion takes no account of the stronger 1,3-diaxial interactions present in the dioxane ring because of the shorter $\mathrm{C}-\mathrm{O}$ bonds. (The A-value for the methyl group at room temperature is $1.74 \mathrm{kcal} \mathrm{mol}^{-1}$, but Eliel and Knoeber determined $\Delta G^{\circ}$ for the ring inversion of 2methyl-1,3-dioxane as $>3.5$

$\mathrm{kcal} \mathrm{mol}^{-1} .^{11}$ Making no allowance for the stronger interactions in the dioxan, these data would suggest a strong reverse anomeric effect for the methyl group!)

The method of Franck allows predictions of the effective sizes of substituents on saturated heterocyclic rings by comparing values of $\Delta G^{\circ}$ for the ring-inversion of substituted systems with A-values for the same equilibria in similarly substituted cyclohexanes. ${ }^{12}$ The $A$-value of the methyl group, for example, is compared with the standard conformational free energy change for the ring inversion of the methyl-substituted dioxane ring, and the same proportionality factor applied to A-values of other groups. Franck's original paper compared the sizes of 'inert' groups like methyl, in cyclohexyl and tetrahydropyranyl systems, but the method is simply extended to 1,3-dioxane and other saturated heterocyclic systems. ${ }^{13}$ With steric corrections taken into account, Franck concluded that $\mathrm{NMe}_{2}$ and NHMe groups actually show a slight anomeric effect. $^{12}$

\section{Results and Discussion}

We studied amide acetal 6 to provide some insight into the magnitude of the anomeric effect of the dimethylamino group, by comparing $\Delta G^{\circ}$ for ring inversion with that of its cyclohexyl analogue 7. As in our original system 5 the geminal methyl group acts as a steric counterbalance to the $\mathrm{NMe}_{2}$ group. In the analysis, we assume, with Franck, that both groups experience the same degree of steric compression on going from the cyclohexane to the dioxane ring. If there is no anomeric effect in dioxane $\mathbf{6}$ the equilibrium constants for the ring inversion of $\mathbf{6}$ and $\mathbf{7}$ (Scheme 1) should be the same. 
<smiles>CC1COCC1OC(C)(C)N(C)C</smiles>

$6 e$

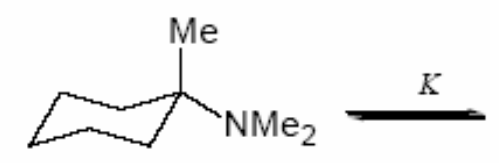

$7 e$
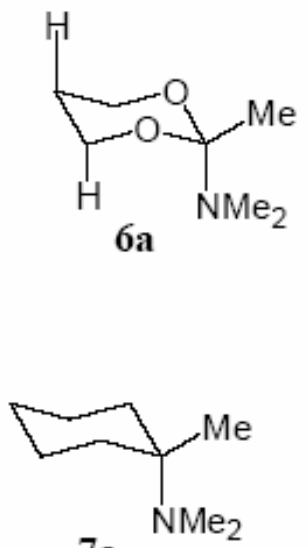

$7 a$

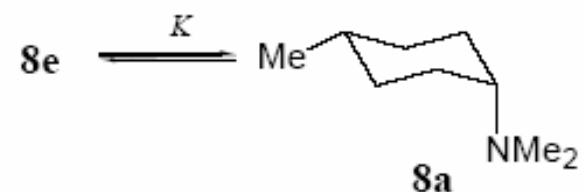

\section{Scheme 1}

We can compare our data for the ring inversion of amine 7 with the results of Booth and Jozefowicz, who measured the equilibrium constant for the related amine $\mathbf{8}$ in order to determine the $A$-value for the dimethylamino group. ${ }^{14}$ In this system the 4-methyl group was used as a counterbalance, so the value for $-\Delta G^{\circ}$ was subtracted from the $A$-value for the methyl group (taken as $1.7 \mathrm{kcal} \mathrm{mol}^{-1}=7.11 \mathrm{~kJ} \mathrm{~mol}^{-1}$ ) to give $A$-values for the dimethylamino group of $6.40 \mathrm{~kJ} \mathrm{~mol}^{-1}\left(1.53 \mathrm{kcal} \mathrm{mol}^{-1}\right)$ in $\mathrm{CFCl}_{3}: \mathrm{CDCl}_{3} 9: 1$ and $5.48 \mathrm{~kJ} \mathrm{~mol}^{-1}\left(1.31 \mathrm{kcal} \mathrm{mol}^{-1}\right)$ in toluene. ${ }^{14}$ In our system 7 the equilibrium constant for the ring inversion is closely similar (Table 1), and we conclude that, at least in this geminally disubstituted compound, there is little or no interaction between the two groups.

Table 1 Comparison of equilibrium constants for ring inversion of $N, N, 1$ - and $N, N, 4-$ trimethylcyclohexylamines $\mathbf{7}$ and $\mathbf{8}$

\begin{tabular}{ccccc}
\hline Compound & Solvent & Temperature $/ \mathrm{K}$ & $K$ & $-\Delta G^{\circ} /$ \\
\hline & & & & $\mathrm{kJ}$ mol-1 \\
$\mathbf{8} 14$ & $\mathrm{CFCl}_{3}: \mathrm{CDCl}_{3} 9: 1$ & 183 & 1.61 & 0.71 \\
$\mathbf{8} 14$ & toluene- $d_{8}$ & 183 & 3.0 & 1.63 \\
7 & $\mathrm{CFCl}_{3}: \mathrm{CDCl}_{3} 9: 1$ & 180 & $2.81 \pm 0.07$ & $1.55 \pm 0.03$ \\
7 & $\mathrm{CFCl}_{3}: \mathrm{CD}_{2} \mathrm{Cl}_{2} 9: 1$ & 185 & $2.82 \pm 0.04$ & $1.59 \pm 0.03$ \\
\hline
\end{tabular}


Table 2 Equilbrium constants and standard free energies for the ring inversion of $\mathbf{7}$ at different temperatures

\begin{tabular}{ccc}
\hline Temperature $/ \mathrm{K}$ & $K$ & $-\Delta G^{\circ}$ \\
\hline 190 & $2.90 \pm 0.11$ & $1.68 \pm 0.06$ \\
185 & $2.82 \pm 0.04$ & $1.59 \pm 0.03$ \\
180 & $2.81 \pm 0.07$ & $1.55 \pm 0.03$ \\
175 & $2.83 \pm 0.04$ & $1.51 \pm 0.02$ \\
170 & $3.00 \pm 0.08$ & $1.55 \pm 0.04$ \\
\hline
\end{tabular}

A plot of $\ln K$ against $1 / \mathrm{T}$ gave the thermodynamic parameters as: $\Delta H^{\circ}=-0.41 \pm 0.48 \mathrm{~kJ} \mathrm{~mol}^{-1}, \Delta S^{\circ}=6.5 \pm 3 \mathrm{~J} \mathrm{~K}^{-1} \mathrm{~mol}^{-1}$

We note that for the ring inversion of amine $7, \Delta H^{\circ}$ is zero (within experimental error, Table 2) and $\Delta S^{\circ}$ is positive, i.e. $\Delta G^{\circ}$ is predicted to vary with temperature. This positive entropy difference for the ring inversion is unexpected. When the dimethylamino group is axial, the conformation is restricted to the single rotamer, 7a(i), with the lone pair over the ring - rotamers with methyl groups over the ring are much higher in energy (Scheme 2). When the group is equatorial rotamer $\mathbf{7 e ( i ) ~ s h o u l d ~ b e ~ m o s t ~ f a v o r a b l e , ~ t h o u g h ~ r o t a m e r s ~} \mathbf{7 e ( i i ) ~ a n d ~ ( i i i ) ~ s h o u l d ~ n o t ~ b e ~}$ inaccessibly high in energy.

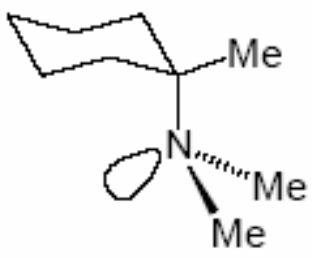

$7 \mathbf{a}(\mathbf{i})$

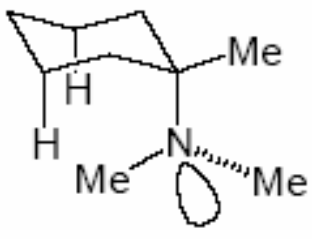

7 a(ii)

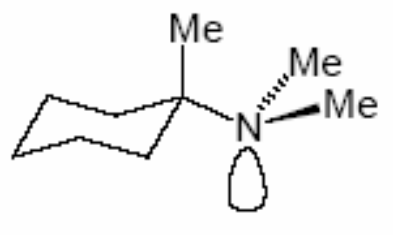

$7 e(i)$

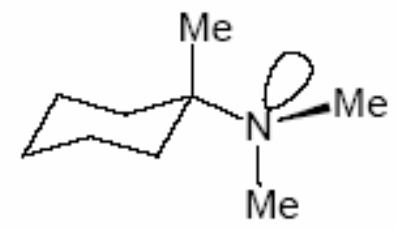

$7 \mathbf{e}(\mathrm{ii})$

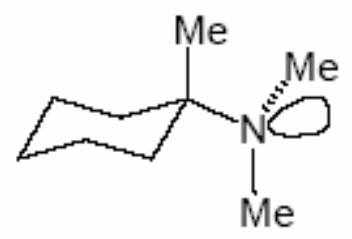

$7 e($ iii)

\section{Scheme 2}

Thus the simple prediction is that the conformation with the dimethylamino group equatorial should have the greater entropy, the opposite to what is observed. Höfner et al. also observed a small positive entropy change $\left(\Delta S^{\circ}=1.8 \mathrm{~kJ} \mathrm{~mol}^{-1}\right)$ when the methoxy group in 
methoxycyclohexane goes from equatorial to axial. ${ }^{15}$ They point out that many other contributions to the entropy change that must be considered besides rotational factors, and try and quantify some of these. Praly and Lemieux, who analysed solvent contributions to entropy changes, suggest stronger solvation of the equatorial conformer of 2-methoxytetrahydropyran to explain the positive $\Delta S_{\text {eq } \rightarrow \text { ax. }}^{\circ}{ }^{16}$

Our objective was to compare the free energy changes for the ring inversions of amine 7 and amide acetal 6, using low temperature ${ }^{~} \mathrm{H}$ NMR. However, on cooling a sample of amide acetal 6 to $140 \mathrm{~K}$ (in $70: 30 \mathrm{CBr}_{2} \mathrm{~F}_{2}: \mathrm{CD}_{2} \mathrm{Cl}_{2}$ ), no trace was observed of the conformer with the $\mathrm{NMe}_{2}$ group equatorial. This could mean either the temperature was not low enough for the two conformers to be in slow exchange, or there was only the one conformer present. Since there was no significant change in appearance of the lowest temperature spectra, although dioxanes are usually in slow exchange well above $150 \mathrm{~K}$, we conclude that the amide acetal exists effectively as a single conformer. nOe experiments tell us that the conformation present is $6 \mathbf{6}$.

The coupling constants in the ${ }^{1} \mathrm{H}$ NMR spectra of 6 (Table 3) are consistent with this conclusion. Were the amide acetal in rapid equilibrium with its conformer, the coupling constant between the protons on $\mathrm{C}(4)$ and $\mathrm{C}(5)$ would represent a weighted average of the coupling constants in the two conformations (see Scheme 1). The trans-diaxial coupling constant between 4Hax and 5Hax is so large $(12.7 \mathrm{~Hz}$, Table 3$)$ that $\mathbf{6 e}$ cannot be present in significant amounts. ${ }^{17}$

Table 3 The ${ }^{1} \mathrm{H}-{ }^{1} \mathrm{H}$ coupling constants in amide acetal 6

\begin{tabular}{cc}
\hline Coupling & Coupling constant $/ \mathrm{Hz}$ \\
\hline${ }^{2} J_{\mathrm{H} 4 \mathrm{ax}-\mathrm{H} 4 \mathrm{eq}}$ & -11.4 \\
${ }^{3} J_{\mathrm{H} 4 \mathrm{ax}-\mathrm{H} 5 \mathrm{ax}}$ & 12.7 \\
${ }^{3} J_{\mathrm{H} 4 \mathrm{ax}-\mathrm{H} 5 \mathrm{eq}}$ & 2.8 \\
${ }^{3} J_{\mathrm{H} 4 \mathrm{eq}-\mathrm{H} 5 \mathrm{ax}}$ & 5.2 \\
${ }^{3} J_{\mathrm{H} 4 \mathrm{eq}-\mathrm{H} 5 \mathrm{eq}}$ & 1.4 \\
${ }^{2} J_{\mathrm{H} 5 \mathrm{ax}-\mathrm{H} 5 \mathrm{eq}}$ & -13.2 \\
\hline
\end{tabular}

If the steric compression experienced by the methyl and dimethylamino groups increases by the same factor on going from the cyclohexane to the dioxane (as assumed in Franck's method), then the equilibrium constants for the ring inversions of the two compounds should be the same. At $185 \mathrm{~K}$, the $\mathrm{NMe}_{2}$ axial conformation for the cyclohexane compound is more favourable by $\Delta G^{\circ}=1.59 \mathrm{~kJ} \mathrm{~mol}^{-1}$, whereas for the dioxane analogue (assuming, conservatively, a maximum ratio, axial:equatorial 95:5 for $\mathrm{NMe}_{2}$ ), the $\mathrm{NMe}_{2}$ axial conformation $\mathbf{6 a}$ is favoured by $\Delta G^{\circ} \geq 4.5$ $\mathrm{kJ} \mathrm{mol}^{-1}$. Hence, the conformation of dioxane 6 with the axial $\mathrm{NMe}_{2}$ group is at least $3 \mathrm{~kJ} \mathrm{~mol}^{-1}$ more stable at $185 \mathrm{~K}$ than would be expected from steric factors alone.

This result can be used to shed some light on the exo/endo anomeric effects in the 2aminotetrahydropyrans studied extensively by Booth et al.. ${ }^{9,18,19}$ Because nitrogen is less electronegative than oxygen it is a better donor, and $\sigma * \mathrm{C}-\mathrm{N}$ a weaker acceptor of electrons 
than $\sigma * \mathrm{C}-\mathrm{O}$. So 2-methylaminotetrahydropyran should exhibit a stronger exoanomeric effect $\left(\mathrm{n}_{\mathrm{N}}-\sigma^{*}{ }_{\mathrm{C}-\mathrm{O}}\right)$ than endo-anomeric effect $\left(\mathrm{n}_{\mathrm{O}}-\sigma^{*}{ }_{\mathrm{C}-\mathrm{O}}\right)$. Thus, as shown by Booth et al., in contrast to 2-methoxytetrahydropyran, 2-methylaminotetrahydropyran actually prefers the equatorial conformation (Scheme 3). ${ }^{19}$

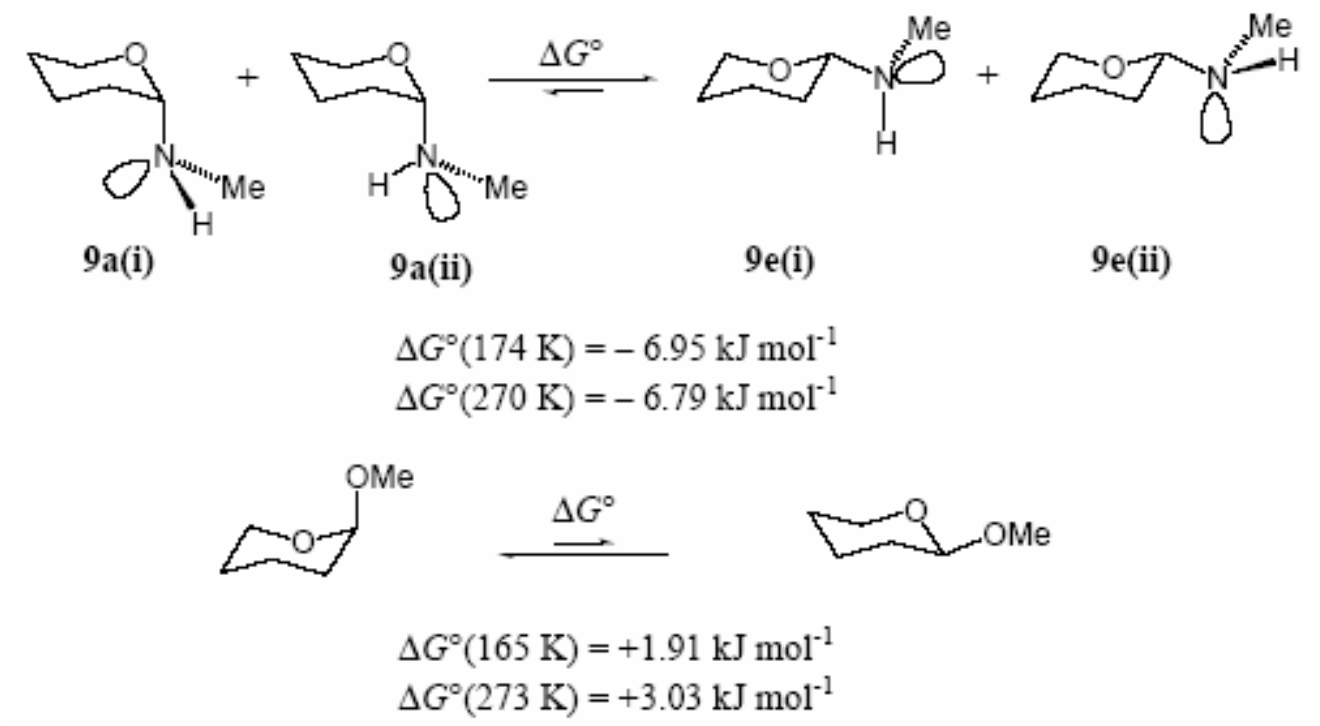

\section{Scheme 3}

By studying homo- and hetero-nuclear coupling constants in 9e and $\mathbf{9 a}$, these authors were able to confirm the preference for rotamers exhibiting an exo-anomeric effect (Scheme 3). With the NHMe group equatorial rotamer 9e(i), stabilised by an exoanomeric effect, is preferred. With NHMe axial the preference is for rotamer 9a(ii): for the same reason, even though this means that the hydrogen atom must lie above the ring.

These results, together with the finding that 2-dimethylaminotetrahydropyran also prefers the conformation with the $\mathrm{NMe}_{2}$ group equatorial, ${ }^{20}$ prompted Eliel et al. to conclude that "in [2dimethylamino-and 2-methylamino-tetrahydropyrans], the equatorial isomer is actually favoured since the exo-anomeric effect now outweighs the endo-anomeric effect". ${ }^{21}$ Our results show that in $N, N, 2$-trimethyl-2-amino-1,3-dioxane the dimethylamino group prefers the axial conformation: even when size factors are taken into account, the exo-anomeric effect does not outweigh the endo-anomeric effect.

In contrast to the $\mathrm{N}$-methylaminotetrahydropyrans, no exo-anomeric effect is expected when the dimethylamino group is axial in the 2-position on a dioxane ring, because in order for the nitrogen lone pair to be anti to a $\mathrm{C}-\mathrm{O}$ bond, a methyl group would have to lie over the ring (6a(ii), Scheme 4). This is possible for a hydrogen (cf. 9a(i)), but the steric demands of a methyl group are prohibitive.

The question then arises, is an exo-anomeric effect still possible when the $\mathrm{NMe}_{2}$ group is equatorial? For an exo-anomeric effect to be possible (rotamer 6e(i)), one of the methyl groups 
on the nitrogen must align itself in an axial-like position (Scheme 4). Though sterically less favourable than rotamer $\mathbf{6 e}(\mathbf{i i})$, this should be possible, since the eclipsing 1,3-interactions are with lone pairs on oxygen. For guidance we have performed $a b$ initio calculations on $\mathbf{6}$ and $\mathbf{7}$.

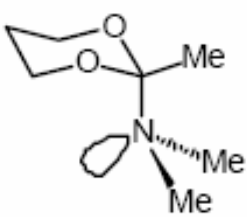

6a(i)

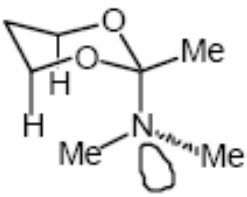

6a(ii)

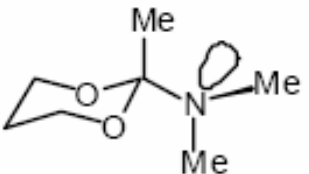

$6 e(i)$

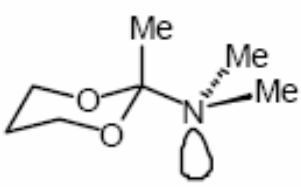

6e(ii)

\section{Scheme 4}

\section{Calculations}

Calculations on the energies of different conformers of 6 and 7 proved illuminating. Results using MM2 and a 6-31G* basis set are compared in Table 4. Both techniques predict the order that is observed experimentally, with the conformation with the $\mathrm{NMe}_{2}$ group axial preferred in both cyclohexane and dioxane systems. For the dioxane, conformation $\mathbf{6 a ( i )}$, with the $\mathrm{NMe}_{2}$ group axial, is substantially lower in energy than the equatorial pair $\mathbf{6 e ( i )}$ and (ii). However conformation $\mathbf{6 e ( i )}$ is lower in energy than $\mathbf{6 e ( i i ) . ~}$

This is contrary to the order observed in the cyclohexane and suggests that when the $\mathrm{NMe}_{2}$ group is equatorial, an exo-anomeric effect is possible.

If a strong exo-anomeric effect is in fact possible when the dimethylamino group is equatorial, we might have expected to see at least some evidence of this conformation. Perhaps another reason why this is not observed is that in the dioxane, it is possible for both ring oxygen atoms to interact with the $\sigma^{*} \mathrm{C}-\mathrm{N}$ orbital in the conformation with the $\mathrm{NMe}_{2}$ group is axial, while the single lone pair on the nitrogen can interact with only one $\sigma^{*} \mathrm{C}-\mathrm{O}$ orbital when equatorial. 
Table 4 Results of theoretical calculations on conformers of $\mathbf{6}$ and $\mathbf{7}$

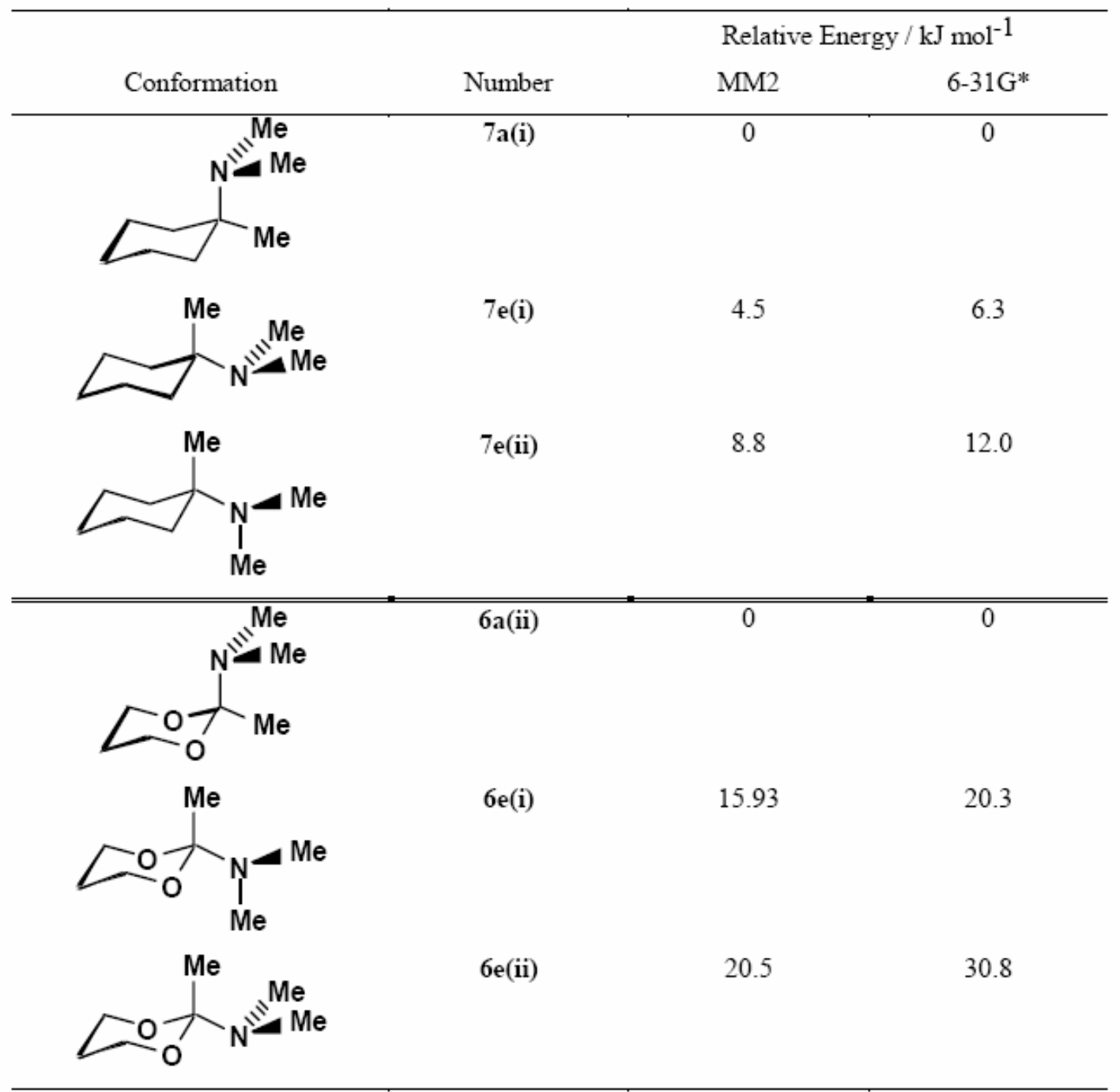

\section{Conclusions}

N,N,2-trimethyl-2-amino-1,3-dioxane 6, like its 5,5-dimethyl derivative 5, exists apparently exclusively in the conformation with the dimethylamino-group axial. We conclude that the endoanomeric effect in this system is greater than the exo-anomeric effect, even though amine nitrogen is generally a better electron-pair donor than oxygen. 


\section{Experimental Section}

Low-temperature ${ }^{1} \mathbf{H}$ NMR measurements. We determined the thermodynamic parameters for the ring inversion of amine 7 by direct measurement of the conformational equilibrium constants using low-temperature ${ }^{1} \mathrm{H}$ NMR spectra. At room temperature, the NMe2 protons and the Cmethyl protons appear as singlets at $2.22 \mathrm{ppm}$ and $0.88 \mathrm{ppm}$ respectively, and both are separated from other signals by at least $0.35 \mathrm{ppm}$. However, the peaks due to the $\mathrm{NMe}_{2}$ protons in the two conformations are too close together $(\delta 2.14 \mathrm{ppm}$ and $2.11 \mathrm{ppm})$ for accurate determination of their relative proportions. At $200 \mathrm{~K}$, the signal due to the C-methyl group has separated into two clearly resolved peaks - the smaller at $0.86 \mathrm{ppm}$ (from the conformation with the methyl group axial) and the larger at $0.76 \mathrm{ppm}$ (methyl group equatorial). A series of spectra recorded at temperatures between $298 \mathrm{~K}$ and $190 \mathrm{~K}$ show progressive changes in the ${ }^{1} \mathrm{H}$ NMR spectra of 7.

For the quantitative measurements, samples were made up to approximately $0.1 \mathrm{~mol} \mathrm{dm}^{-3}$ in 9:1 $\mathrm{CFCl}_{3}: \mathrm{CD}_{2} \mathrm{Cl}_{2}$. Spectra were recorded on a Bruker AM400 spectrometer in $5 \mathrm{~mm}$ tubes. Samples were allowed to equilibrate at $5 \mathrm{~K}$ intervals from $190 \mathrm{~K}$ to $175 \mathrm{~K}$ and four spectra were recorded at each temperature. The resulting spectra were plotted over the region of the methyl peaks for the two conformers and then expanded further by photocopying. The two peaks were then cut out, accurately weighed and the masses used to determine the conformational equilibrium constants using the following equation:

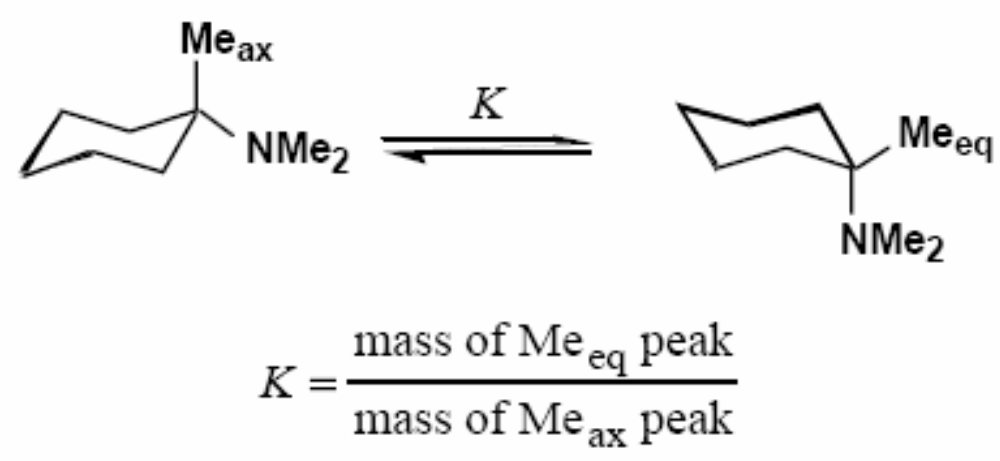

The four values of $K$ for each temperature were then averaged to give the values shown in Table 2.

\section{Experimental Section}

General Procedures. All solvents were distilled before use and dried, unless otherwise indicated, by stirring over, then distilling from, a suitable drying agent: lithium aluminium hydride for tetrahydrofuran and diethyl ether; calcium hydride for dichloromethane, hexane, toluene and cyclohexane and phosphorus pentoxide for glacial acetic acid. Commercial 
cyclohexanol, which contains trace amounts of cyclohexanone was purified by cooling and filtering off the pure solid cyclohexanol (freezing point $24^{\circ} \mathrm{C}$ ) and then distilling.

Merck Kieselgel 60 (230-400 mesh) was used for flash column chromatography. Merck Kieselgel $60 \mathrm{~F} 254$ pre-coated plates $(0.25 \mathrm{~mm})$ were used for thin layer chromatography and the products were visualized with iodine vapor or potassium permanganate solution.

Melting points were measured with a Reichert hot stage microscope and are uncorrected. Infrared spectra were recorded on a Perkin-Elmer 1600 FTIR spectrophotometer. Proton and carbon NMR spectra were recorded on a Bruker AC 200, Bruker WM 250, Bruker AM 400 or a Bruker DRX 500 Fourier transform spectrometer. Mass spectra were recorded on an AEI Kratos MS30 or an AEI Kratos MS890 machine. A DS503 data system was used for high resolution analysis. Microanalyses were carried out by the staff of the University Chemical Laboratories using Carlo Erba 1106 or Perkin-Elmer 240 automatic analysers.

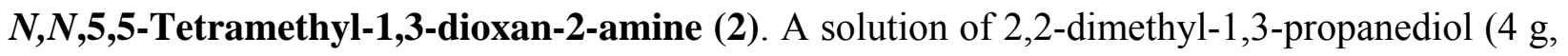
$39 \mathrm{mmol}$ ) and a crystal of $p$-toluenesulphonic acid were heated in dry toluene to $90{ }^{\circ} \mathrm{C}$ under argon, and $N, N$-dimethylformamide dimethyl acetal $(5 \mathrm{~g}, 42 \mathrm{mmol}$ ) added drop wise. The methanol formed was distilled out as the azeotrope with toluene, the solution cooled, washed with sodium bicarbonate solution $(25 \mathrm{~mL})$ and brine $(25 \mathrm{~mL})$, dried $\left(\mathrm{MgSO}_{4}\right)$ and evaporated under reduced pressure. The residue was distilled to give the amide acetal $(3.27 \mathrm{~g}, 53 \%)$, bp 56$57{ }^{\circ} \mathrm{C} / 7 \mathrm{mmHg}$. (lit. ${ }^{21} 68-70{ }^{\circ} \mathrm{C} / 7 \mathrm{mmHg}$ ); IR: $v_{\max }\left(\right.$ Film) $/ \mathrm{cm}^{-1} 2953$ and $2870(\mathrm{C}-\mathrm{H}), 1111$ and $1097(\mathrm{C}-\mathrm{O}) ;{ }^{1} \mathrm{H}$ NMR $\left(200 \mathrm{MHz} ; \mathrm{CDCl}_{3}\right) \delta 4.71$ (1 H, s, H2), 3.62 (1 H, d, J 10, H4 eq and H6 $\left.6_{\mathrm{eq}}\right)$, $3.47\left(1 \mathrm{H}, \mathrm{d}, \mathrm{J} 10, \mathrm{H}_{\mathrm{ax}}\right.$ and $\left.\mathrm{H}_{\mathrm{ax}}\right), 2.40\left(6 \mathrm{H}, \mathrm{s},-\mathrm{N}\left(\mathrm{CH}_{3}\right)_{2}\right), 1.17\left(3 \mathrm{H}, \mathrm{s}, \mathrm{C} 5-\mathrm{Me}_{\mathrm{ax}}\right)$ and $0.73(3 \mathrm{H}$, s, C5-Me $\mathrm{eq}) ;{ }^{13} \mathrm{C} \mathrm{NMR}\left(\mathrm{CDCl}_{3}\right) \delta 108.8(\mathrm{C} 2), 76.2(\mathrm{C} 4$ and $\mathrm{C} 6), 37.7\left(-\mathrm{N}\left(\mathrm{CH}_{3}\right)_{2}\right), 29.7(\mathrm{C} 5), 22.8$ $\left(-\left(\mathrm{CH}_{3}\right)_{\mathrm{ax}}\right)$ and $21.4\left(-\left(\mathrm{CH}_{3}\right)_{\mathrm{eq}}\right)\left(\right.$ Anal. $\mathrm{C}_{8} \mathrm{H}_{17} \mathrm{NO}_{2}$ Found: $\mathrm{C}, 60.15 ; \mathrm{H}, 10.70 ; \mathrm{N}, 8.75$. Requires $\mathrm{C}$, $60.35 ; \mathrm{H}, 10.75 ; \mathrm{N}, 8.80 \%)$.

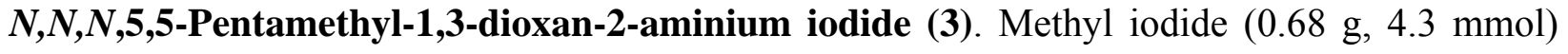
was added to a stirred solution of $N, N, 5,5$-tetramethyl-1,3-dioxan-2-amine 2 (0.75 g, $4.3 \mathrm{mmol})$ in dry ether $(10 \mathrm{~mL})$ and the solution stirred for $36 \mathrm{~h}$ under argon. The precipitate formed was filtered off and washed with ether to give the quaternary amide acetal ${ }^{5}$ as a white powder $(0.92 \mathrm{~g}$, 71\%); IR: $v_{\max }(\mathrm{KBr}) / \mathrm{cm}^{-1} 3014,2968,2864$ and $2738(\mathrm{C}-\mathrm{H}), 1105$ and $1056(\mathrm{C}-\mathrm{O})$; ${ }^{1} \mathrm{HNMR}$ $\left(400 \mathrm{MHz} ; \mathrm{CD}_{2} \mathrm{Cl}_{2}\right) \delta 6.26(1 \mathrm{H}, \mathrm{s}, \mathrm{H} 2), 3.94\left(2 \mathrm{H}, \mathrm{d}, J\right.$ 11, H4 ax and $\left.\mathrm{H} 6_{\mathrm{ax}}\right), 3.81(2 \mathrm{H}, \mathrm{d}, J$ 11, $\mathrm{H}_{4}$ eq and $\left.\mathrm{H}_{\mathrm{eq}}\right), 3.32,\left(9 \mathrm{H}, \mathrm{s},-\mathrm{N}\left(\mathrm{CH}_{3}\right)_{3}{ }^{+}\right), 1.19\left(3 \mathrm{H}, \mathrm{s}, \mathrm{C} 5-\left(\mathrm{CH}_{3}\right)_{\mathrm{ax}}\right)$ and $0.82(3 \mathrm{H}, \mathrm{s}, \mathrm{C} 5-$ $\left.\left(\mathrm{CH}_{3}\right)_{\mathrm{eq}}\right) ;{ }^{13} \mathrm{C} \mathrm{NMR}\left(\mathrm{CD}_{2} \mathrm{Cl}_{2}\right): \delta 106.6(\mathrm{C} 2), 77.0(\mathrm{C} 4$ and $\mathrm{C} 6), 49.1\left(-\mathrm{N}\left(\mathrm{CH}_{3}\right)_{3}{ }^{+}\right), 30.4(\mathrm{C} 5), 22.8$ $\left(\mathrm{C} 5-\left(\mathrm{CH}_{3}\right)_{\mathrm{A}}\left(\mathrm{CH}_{3}\right)_{\mathrm{B}}\right)$ and $20.6\left(\mathrm{C}^{-}\left(\mathrm{CH}_{3}\right)_{\mathrm{A}}\left(\mathrm{CH}_{3}\right)_{\mathrm{B}}\right) ; \mathrm{MS}: \mathrm{m} / \mathrm{z} 115\left(100 \%, \mathrm{M}-\mathrm{NMe}_{3}\right)$; Anal. $\mathrm{C}_{9} \mathrm{H}_{20} \mathrm{NO}_{2} \mathrm{I}$ Found $\mathrm{C}, 35.75 ; \mathrm{H}, 6.70 ; \mathrm{N}, 4.60 ; \mathrm{I}, 41.90$ requires $\mathrm{C}, 35.90 ; \mathrm{H}$ 6.70; N 4.65; I, $42.15 \%)$.

$\boldsymbol{N}, \boldsymbol{N}, \mathbf{2 , 5 , 5 - P e n t a m e t h y l - 1 , 3 - d i o x a n e - 2 - a m i n e ~ ( 5 ) . ~ A ~ s o l u t i o n ~ o f ~ 2 , 2 - d i m e t h y l - 1 , 3 - p r o p a n e d i o l ~}$ $(1.25 \mathrm{~g}, 12 \mathrm{mmol})$ and a crystal of $p$-toluenesulphonic acid in dry toluene $(30 \mathrm{~mL})$ was heated to $90{ }^{\circ} \mathrm{C}$ under argon and $N, N$-dimethylacetamide dimethyl acetal $(2 \mathrm{~g}, 15 \mathrm{mmol})$ added dropwise. The methanol-toluene azeotrope formed was distilled out and the solution stirred for $3 \mathrm{~h}$ at 
$90{ }^{\circ} \mathrm{C}$. The solution was cooled, evaporated under reduced pressure and the residue distilled to give the amide acetal $(0.79 \mathrm{~g}, 38 \%)$ as a colourless oil, bp $44-46{ }^{\circ} \mathrm{C} / 6 \mathrm{mmHg}$; IR: $v \max \left(\right.$ Film) $/ \mathrm{cm}^{-1}$ 2997, 2945 and 2867 (C-H), 2821 and $2783\left(\mathrm{NMe}_{2} \mathrm{C}-\mathrm{H}\right), 1372\left(\mathrm{Nme}_{2}\right), 1225$, 1200, 1184, 1134, 1079 and $1037(\mathrm{C}-\mathrm{O}) ;{ }^{1} \mathrm{H}$ NMR $\left(200 \mathrm{MHz} ; \mathrm{CDCl}_{3}\right) 3.82\left(2 \mathrm{H}, \mathrm{d}, \mathrm{J} 10, \mathrm{H} 4_{\mathrm{ax}}\right.$ and $\left.\mathrm{H}_{6 \mathrm{ax}}\right), 3.10\left(2 \mathrm{H}, \mathrm{d}, J 10, \mathrm{H}_{\mathrm{eq}}\right.$ and $\left.\mathrm{H}_{\mathrm{eq}}\right), 2.20\left(6 \mathrm{H}, \mathrm{s},-\mathrm{N}\left(\mathrm{CH}_{3}\right)_{2}\right), 1.20\left(3 \mathrm{H}, \mathrm{s}, \mathrm{C}_{2}-\mathrm{CH}_{3}\right)$, $1.16\left(3 \mathrm{H}, \mathrm{s},\left(\mathrm{C} 5-\left(\mathrm{CH}_{3}\right)_{\mathrm{ax}}\right)\right.$ and $0.72\left(3 \mathrm{H}, \mathrm{s},\left(\mathrm{C} 5-\left(\mathrm{CH}_{3}\right)_{\mathrm{eq}}\right) ;{ }^{13} \mathrm{C} \mathrm{NMR}\left(\mathrm{CDCl}_{3}\right) 105.9(\mathrm{C} 2), 68.9\right.$ (C4 and $\mathrm{C} 6), 37.5\left(-\mathrm{N}\left(\mathrm{CH}_{3}\right)_{2}\right), 29.1(\mathrm{C} 5), 23.3\left(\mathrm{C} 5-\left(\mathrm{CH}_{3}\right)_{\mathrm{ax}}\right), 22.1\left(\mathrm{C} 5-\left(\mathrm{CH}_{3}\right)_{\mathrm{eq}}\right)$ and $15.9(\mathrm{C} 2-$ $\left.\mathrm{CH}_{3}\right) ; \mathrm{m} / \mathrm{z} 173\left(5 \%, \mathrm{M}^{+}\right)$and $129\left(100, \mathrm{M}-\mathrm{NMe}_{2}\right)$; Anal. $\mathrm{C}_{9} \mathrm{H}_{19} \mathrm{NO}^{2}$. Found: $\mathrm{M}^{+}, 173.1407$ requires $M, 173.1416$ )(Found: $\mathrm{C}, 62.30 ; \mathrm{H}, 11.20 ; \mathrm{N}, 7.90 . \mathrm{C}_{9} \mathrm{H}_{19} \mathrm{NO}_{2}$ requires $\mathrm{C}, 62.40 ; \mathrm{H}$, $11.05 ; \mathrm{N}, 8.10 \%$ ). NOE results (Table 5 ) established the conformation (see above).

Table 5 Results of nOe experiments on 5

\begin{tabular}{ccccccc}
\hline $\begin{array}{c}\text { Signal } \\
\text { irradiated }\end{array}$ & \multicolumn{7}{c}{ Percentage nOe detected } \\
\hline $\mathrm{C}(2)-\mathrm{Me}$ & $\mathrm{NMe}_{2}$ & $\mathrm{H}(4)_{\mathrm{ax}}$ & $\mathrm{H}(4)_{\mathrm{eq}}$ & $\mathrm{C}(5-\mathrm{Me})_{\mathrm{eq}}$ & $\mathrm{C}(5-\mathrm{Me})_{\mathrm{ax}}$ \\
$\mathrm{NMe}_{2}$ & $\times$ & $?$ & - & - & - & - \\
$\mathrm{H}(4)_{\mathrm{ax}}$ & - & $\times$ & 2.6 & - & - & - \\
$\mathrm{H}(4)_{\mathrm{eq}}$ & - & 1 & $\times$ & 18 & 1.8 & - \\
$\mathrm{C}(5-\mathrm{Me})_{\mathrm{eq}}$ & - & - & 16 & $\times$ & 1.1 & 1.3 \\
$\mathrm{C}(5-\mathrm{Me})_{\mathrm{ax}}$ & - & - & 3.2 & 2.0 & $\times$ & 0.6 \\
\hline
\end{tabular}

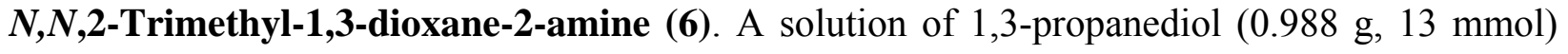
and a crystal of $p$-toluenesulphonic acid in dry toluene $(20 \mathrm{~mL})$ was heated to $100{ }^{\circ} \mathrm{C}$ under argon and $N, N$-dimethylacetamide dimethyl acetal $(2.19 \mathrm{~g}, 16 \mathrm{mmol})$ added dropwise. The methanol-toluene azeotrope formed was distilled out and the solution stirred for $1 \mathrm{~h}$ at $100{ }^{\circ} \mathrm{C}$. The solution was cooled, evaporated under reduced pressure and the residue distilled to give the amide acetal (0.84 g, $44 \%$ ) as a colorless oil, bp $44-46{ }^{\circ} \mathrm{C} / 12 \mathrm{mmHg}$; IR: $v_{\max }\left(\right.$ film) $/ \mathrm{cm}^{-1} 2996$, 2948 and $2878(\mathrm{C}-\mathrm{H}), 2821$ and $2783\left(\mathrm{NMe}_{2}\right), 1249,1214,1188,1146,1125,1080$ and 1050 (C-O); ${ }^{1} \mathrm{H}$ NMR (400 MHz; $\left.\mathrm{CDCl}_{3}\right) \delta 4.13\left(2 \mathrm{H}\right.$, ddd, $J$ 12.7, 11.5 and 2.8, $\mathrm{H}_{\text {ax }}$ and $\mathrm{H6}_{\mathrm{ax}}$ ), 3.57 $\left(2 \mathrm{H}\right.$, ddd, $J 11.3,5.2$ and 1.3, $\mathrm{H}_{4}$ eq and $\left.\mathrm{H}_{\mathrm{eq}}\right), 2.21\left(6 \mathrm{H}, \mathrm{s},-\mathrm{N}\left(\mathrm{CH}_{3}\right)_{2}\right), 2.01(1 \mathrm{H}, \mathrm{qt}, J 12.9$ and 5.2, $\left.\mathrm{H}_{\mathrm{ax}}\right), 1.31\left(1 \mathrm{H}, \mathrm{dtt}, J 13.2,2.8\right.$ and $\left.1.4, \mathrm{H}_{\mathrm{eq}}\right)$ and $1.16\left(3 \mathrm{H}, \mathrm{s}, \mathrm{C} 2-\mathrm{CH}_{3}\right) ;{ }^{13} \mathrm{C} \mathrm{NMR}$

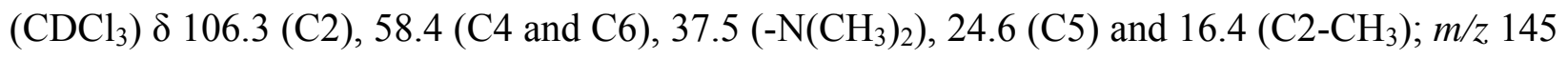
$\left(100 \%, \mathrm{M}^{+}\right), 130(25, \mathrm{M}-\mathrm{Me})$ and $101\left(100, \mathrm{M}-\mathrm{NMe}_{2}\right)$; HRMS: $\mathrm{C}_{7} \mathrm{H}_{15} \mathrm{NO}_{2}$ Found $\mathrm{M}^{+}$, 145.1097, requires $M, 145.1103$; Anal. $\mathrm{C}_{7} \mathrm{H}_{15} \mathrm{NO}_{2}$ Found: C, 58.00; H, 10.55; N, 9.50 requires C, 57.90; H 10.50; N, 9.65\%).

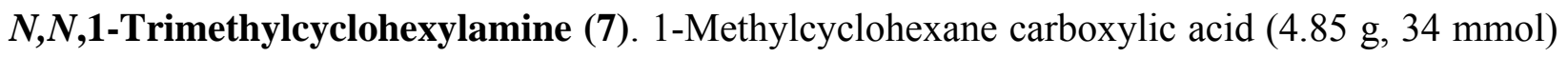
was added to freshly distilled thionyl chloride $(40 \mathrm{~mL})$ and heated under reflux for $2 \mathrm{~h}$. The mixture was evaporated under reduced pressure and the residue distilled to give the acid chloride $^{22}\left(4.26 \mathrm{~g}, 78 \%\right.$ ) as a yellow oil, bp $80-81{ }^{\circ} \mathrm{C} / 20 \mathrm{mmHg}\left(\right.$ lit. ${ }^{22} 81{ }^{\circ} \mathrm{C} / 20 \mathrm{mmHg}$ ); IR: 
$v_{\max }($ film $) / \mathrm{cm}^{-1} 2937$ and $2857(\mathrm{C}-\mathrm{H})$ and $1789(\mathrm{C}=\mathrm{O}) ;{ }^{1} \mathrm{H}$ NMR $\left(200 \mathrm{MHz} ; \mathrm{CDCl}_{3}\right): \delta$ 2.17$1.23(13 \mathrm{H}$, multiplet including $3 \mathrm{H}$ singlet at 1.28$) ;{ }^{13} \mathrm{C} \mathrm{NMR}\left(\mathrm{CDCl}_{3}\right): \delta 180.1$ (-COCl), 53.7 (C1), 35.9 (C2 and C6), $25.8\left(-\mathrm{CH}_{3}\right), 25.3$ (C4) and 22.8 (C3 and $\left.\mathrm{C} 5\right)$; MS: $\mathrm{m} / \mathrm{z} 125$ (80\%, M $\mathrm{Cl})$. The acid chloride $(4.4 \mathrm{~g}, 27.4 \mathrm{mmol})$ was dissolved in ether $(50 \mathrm{~mL})$, cooled to $0{ }^{\circ} \mathrm{C}$ and dry ammonia gas bubbled through for $2 \mathrm{~h}$ with stirring. The mixture was then washed with water $(40 \mathrm{~mL})$, the aqueous layer extracted with ether $(2 \times 30 \mathrm{~mL})$ and the combined ether layers washed again with water $(30 \mathrm{~mL})$. The extract was dried $\left(\mathrm{MgSO}_{4}\right)$ and evaporated under reduced pressure to leave the amide ${ }^{22}(3.1 \mathrm{~g}, 79 \%)$ as a white solid which was used without further purification; $\mathrm{mp} 66-68{ }^{\circ} \mathrm{C}$ (lit. $\left.{ }^{22} 68{ }^{\circ} \mathrm{C}\right) ; R_{\mathrm{f}}\left(\right.$ EtOAc) 0.40; IR: $v_{\max }(\mathrm{KBr}) / \mathrm{cm}^{-1} 3435,3401$ and $3198(\mathrm{~N}-\mathrm{H}), 2919$ and $2857(\mathrm{C}-\mathrm{H}), 1649(\mathrm{C}=\mathrm{O})$ and $1612\left(-\mathrm{CONH}_{2}\right) ;{ }^{1} \mathrm{H} \mathrm{NMR}(200 \mathrm{MHz}$; $\left.\mathrm{CDCl}_{3}\right) 6.06\left(1 \mathrm{H}\right.$, br s, $\left.-\mathrm{NH}_{\mathrm{A}} \mathrm{H}_{\mathrm{B}}\right), 5.70\left(1 \mathrm{H}\right.$, br s, $\left.-\mathrm{NH}_{\mathrm{A}} \mathrm{H}_{\mathrm{B}}\right), 1.91-1.25(10 \mathrm{H}, \mathrm{m})$ and $1.16(3 \mathrm{H}$, $\left.\mathrm{s},-\mathrm{CH}_{3}\right) ;{ }^{13} \mathrm{C} \mathrm{NMR} \delta \mathrm{C}\left(\mathrm{CDCl}_{3}\right) 180.9\left(-\mathrm{CONH}_{2}\right), 42.6(\mathrm{C} 1), 35.6(\mathrm{C} 2$ and $\mathrm{C} 6), 26.4\left(-\mathrm{CH}_{3}\right), 25.7$ (C4) and 22.8 (C3 and C5); MS: m/z $141\left(33 \%, \mathrm{M}^{+}\right), 126(20, \mathrm{M}-\mathrm{Me})$ and 97 (90, M $\mathrm{CONH}_{2}$ ); Found: $\mathrm{M}^{+}, 141.1152 . \mathrm{C}_{8} \mathrm{H}_{15} \mathrm{NO}$ requires $M, 141.1154$.

Following the procedure of Hamlin and Freifelder, ${ }^{23}$ the finely powered 1methylcyclohexanecarboxamide ( $2 \mathrm{~g}, 14.2 \mathrm{mmol}$ ) was added to a stirred solution of bromine $(2.3 \mathrm{~g}, 14 \mathrm{mmol})$ in $20 \%$ aqueous potassium hydroxide $(40 \mathrm{~mL})$ at $0{ }^{\circ} \mathrm{C}$. The solution was stirred for a further $30 \mathrm{~min}$ before extracting the isocyanate with ether $(2 \times 10 \mathrm{~mL})$. The ether extract was carefully added dropwise to boiling concentrated hydrochloric acid $(10 \mathrm{~mL})$ and the mixture refluxed for $20 \mathrm{~min}$. The mixture was then evaporated under reduced pressure and the residue recrystallized from $\mathrm{EtOH}-\mathrm{Et}_{2} \mathrm{O}$ to give

the amine hydrochloride (1.25 g, 60\%), mp 195-200 ${ }^{\circ} \mathrm{C}$ dec.) (lit. ${ }^{23} 285{ }^{\circ} \mathrm{C}$ dec.) The hydrochloride ( $1 \mathrm{~g}, 6.7 \mathrm{mmol})$ was dissolved in $\mathrm{H} 20(10 \mathrm{~mL}), 20 \%$ aqueous $\mathrm{KOH}(10 \mathrm{~mL})$ added and the mixture extracted with ether $(3 \times 20 \mathrm{~mL})$. The extract was evaporated under reduced pressure and the residue distilled using a Kugelrohr apparatus to give the amine, ${ }^{23}(0.45 \mathrm{~g}, 29 \%)$ as a colorless oil; IR: $v_{\max }\left(\right.$ Film)/cm ${ }^{-1} 3346(\mathrm{~N}-\mathrm{H}), 2925$ and $2857(\mathrm{C}-\mathrm{H}) ;{ }^{1} \mathrm{H}$ NMR (200 MHz; $\left.\mathrm{CDCl}_{3}\right): \delta$ ca. $1.7\left(2 \mathrm{H}\right.$, br s, $\left.\mathrm{NH}_{2}\right), 1.54-1.27\left(10 \mathrm{H}, \mathrm{m},\left(-\mathrm{CH}_{2}-\right)_{5}\right)$ and $1.05\left(3 \mathrm{H}, \mathrm{s},-\mathrm{CH}_{3}\right) ;{ }^{13} \mathrm{C}$ NMR $\left(\mathrm{CDCl}_{3}\right) 48.6(\mathrm{C} 1), 40.7(\mathrm{C} 2$ and $\mathrm{C} 6), 29.5\left(-\mathrm{CH}_{3}\right), 25.8(\mathrm{C} 4)$ and $22.7(\mathrm{C} 3$ and $\mathrm{C} 5)$; HRMS: $m / z 113\left(10 \%, \mathrm{M}^{+}\right), 98(10, \mathrm{M}-\mathrm{Me})$ and $70\left(100, \mathrm{C}_{5} \mathrm{H}_{10}\right)$, Found: $\mathrm{M}^{+}, 113.1204$. $\mathrm{C}_{7} \mathrm{H}_{15} \mathrm{~N}$ requires $M, 113.1204$. Finally, a mixture of the 1 -methylcyclohexylamine $(0.44 \mathrm{~g}$, $3.8 \mathrm{mmol})$, formic acid $(10 \mathrm{~mL})$ and $40 \%$ aqueous formalin $(0.75 \mathrm{~mL})$ was refluxed for $4 \mathrm{~h}$. The solution was evaporated under reduced pressure, $20 \%$ aqueous $\mathrm{NaOH}(10 \mathrm{~mL})$ added and then extracted with ether $(3 \times 10 \mathrm{~mL})$. The extract was washed through a plug of silica with more ether and then evaporated under reduced pressure to give the amine ${ }^{23}(0.16 \mathrm{~g}, 30 \%)$ as a colorless oil, IR: $v_{\max }(\mathrm{Film}) / \mathrm{cm}^{-1} 2931$ and $2815(\mathrm{C}-\mathrm{H})$ and $2776\left(-\mathrm{N}\left(\mathrm{CH}_{3}\right)_{2}\right) ;{ }^{1} \mathrm{H} \mathrm{NMR}(250 \mathrm{MHz}$; $\left.\mathrm{CDCl}_{3}\right): \delta 2.19\left(6 \mathrm{H}, \mathrm{s},-\mathrm{N}\left(\mathrm{CH}_{3}\right)_{2}\right), 1.65-1.29\left(10 \mathrm{H}, \mathrm{m},\left(-\mathrm{CH}_{2}-\right)_{5}\right)$ and $0.84\left(3 \mathrm{H}, \mathrm{s},-\mathrm{CH}_{3}\right) ;{ }^{13} \mathrm{C}$ NMR $\left(\mathrm{CDCl}_{3}\right) \delta 55.0(\mathrm{C} 1), 37.5\left(-\mathrm{N}\left(\mathrm{CH}_{3}\right)_{2}\right), 36.1$ (C2 and $\left.\mathrm{C} 6\right), 26.0(\mathrm{C} 4), 22.1(\mathrm{C} 3$ and $\mathrm{C} 5)$ and $15.6\left(-\mathrm{CH}_{3}\right)$; HRMS: $m / z 141\left(80 \%, \mathrm{M}^{+}\right), 126(50, \mathrm{M}-\mathrm{Me})$ and $70\left(90, \mathrm{C}_{5} \mathrm{H}_{10}\right)$, Found: $\mathrm{M}^{+}$ 141.1521. $\mathrm{C}_{9} \mathrm{H}_{19} \mathrm{~N}$ requires $\left.M, 141.1517\right)$. 


\section{References}

1. Kirby, A. J. The Anomeric Effect and Related Stereoelectronic Effects at Oxygen; SpringerVerlag: Berlin and Heidelberg, 1983.

2. (a) Carballeira, L.; Pérez-Juste, I. J. Comput. Chem. 2000, 6, 462. (b) Salzner, U.; Schleyer, P.von R. Journal of Organic Chemistry 1994, 59, 2138.

3. Jones, P. G.; Kirby, A. J.; Komarov, I. V.; Wothers, P. D. J. Chem. Soc., Chem. Commun. 1998, 1695.

4. Kirby, A. J.; I V. Komarov; Wothers, P. D.; Feeder, N.; Jones, P. G. Pure Appl. Chem. 1999, 71,385 .

5. Costisella, V. B.; Gross, H. J. Prakt. Chem. 1977, 319, 8.

6. Lapuka, L. F.; Chalova, O. B.; Kantor, E. A.; Kiladze, T. K.; Rakhmankulov, D. L. Khim. Geterotsikl. Soedin. 1981, 1182.

7. Pastushenko, E. V.; Lapuka, F. L.; Khatuntsev, I. I.; Zlot'skii, S. S.; Rakhmankulov, D. L. Zh. Obshch. Khim. 1986, 56, 59.

8. Allinger, N. L.; Graham, J. C. J. Org. Chem. 1971, 36, 1688.

9. Eliel, E. L.; Wilen, S. H. Stereochemistry of Organic Compounds; John Wiley \& Sons: New York, 1994; p 696.

10. Booth, H.; Khedhair, K. A. J. Chem. Soc., Chem. Commun. 1985, 467.

11. Eliel, E. L.; Knoebar, M. C. J. Am. Chem. Soc. 1968, 90, 3444.

12. Franck, R. W. Tetrahedron 1983, 39, 3251.

13. Graczyk, P. P.; Mikolajczyk, M. Topics in Stereochemistry 1994, 21, 209.

14. Booth, H.; Jozefowicz, M. L. J. Chem. Soc., Perkin Trans. 2 1976, 895.

15. Höfner, D.; Lesko, S. A.; Binsch, G. Org. Magn. Reson. 1978, 11, 179.

16. Praly, J.-P.; Lemieux, R. U. Can. J. Chem. 1987, 65, 213.

17. Sanders, J. K. M., Personal Communication.

18. Booth, H.; Readshaw, S. A. Tetrahedron 1990, 46, 2097.

19. Booth, H.; Khedhair, K. A.; Readshaw, S. A. Tetrahedron 1987, 43, 4699.

20. de Hoog, A. J. Org. Mag. Res. 1974, 6, 233.

21. Arnold, Z.; Kornilov, M. J. Collect. Czech. Chem. Commun., 1964, 29, 651.

22. Jacquier, R.; Christol, H. Bull. Soc. Chim. Fr. 1957, 596.

23. Hamlin, K. E.; Freifelder, M. J. Am. Chem. Soc. 1953, 75, 369. 